\title{
Vertical transmission of Cryptococcus neoformans from a mother coinfected with human immunodeficiency virus. Case report
}

\author{
Transmissão vertical de Cryptococcus neoformans a partir de mãe co-infectada \\ com 0 vírus da imunodeficiência humana. Relato de caso
}

\author{
Gleusa Castro ${ }^{1}$, Maria Célia Cervi ${ }^{2}$ and Roberto Martinez ${ }^{1}$
}

\begin{abstract}
Disseminated infection with Cryptococcus neoformans was observed in a newborn infant who presented fever and respiratory symptoms since the $52^{\text {nd }}$ day of life. The mother was infected by human immunodeficiency virus and presented pulmonary and meningeal cryptococcal infection. This is a rare case of cryptococcal infection with probable maternal-fetal transmission.
\end{abstract}

Key-words: Cryptococcus neoformans. Acquired immunodeficiency syndrome. Pregnancy. Maternal-fetal transmission. Human immunodeficiency virus.

\section{RESUMO}

Infecção disseminada por Cryptococcus neoformans foi observada em um recém-nascido que apresentava febre e sintomas respiratórios desde 0 52음 dia de vida. A mãe tinha infecção pelo vírus da imunodeficiência humana e apresentou infecção pulmonar e meningite criptocócica. Este é um caso raro de uma infecção criptocócica com provável transmissão materno-fetal.

Palavras-chaves: Cryptococcus neoformans. Síndrome da imunodeficiência adquirida. Gravidez. Transmissão materno-fetal. Vírus da imunodeficiência humana.

Cryptococcosis is a systemic mycosis caused by varieties of Cryptococcus neoformans and is predominantly an opportunistic infection observed in adults with acquired immunodeficiency syndrome (AIDS) or in other cellular immunodeficiency conditions. A Brazilian study showed a $15 \%$ prevalence of cryptococcosis among adults with AIDS 2 . Another prospective study conducted in the United States between 1992 and 2000 reported that $88.7 \%$ of the cases of cryptococcosis were associated with HIV infection ${ }^{6}$.

This is a disease rarely detected in children, even in those immunodepressed, with some reports of older children ${ }^{49}$ and almost nonexistent in newborn infants ${ }^{3}$. There are few reports of cryptococcosis diagnosed during pregnancy ${ }^{1}{ }^{8}$, including isolation of the fungus from the placenta.

The transmission of Cryptococcus from mother to newborn infant with evidence of the disease has been reported previously and is considered to be quite rare?
A case of probable vertical transmission of Cryptococcus neoformans from an HIV-infected mother is described here, with manifestations of pulmonary and disseminated cryptococcosis in an infant by fungal dissemination during the peripartum period.

\section{CASE REPORT}

A 26-year-old patient in the 41st week of pregnancy, with rupture of the fetal membrane 8 hours before, was admitted to the University Hospital of Ribeirão Preto Faculty of Medicine, University of São Paulo. She was from the urban zone of Ribeirão Preto, SP, Brazil, and was an illicit injecting drug user with a diagnosis of HIV-1 infection made during pregnancy, which had not been treated with antiretroviral drugs. She presented a fever and a cough 15 days prior to delivery and a chest X-ray revealed an alveolar infiltrate in the middle third of the left lung. She was treated with amoxicillin.

\footnotetext{
1. Departament of Internal Medicine, Faculty of Medicine of Ribeirão Preto, University of São Paulo, Ribeirão Preto, SP, Brasil. 2 Departament of Pediatric, Faculty of Medicine of Ribeirão Preto, University of São Paulo, Ribeirão Preto, SP, Brasil.

Address to: Prof. Roberto Martinez. Depto de Clínica Médica/FMRP/USP. Av. Bandeirantes 3900, 14048-900 Ribeirão Preto, SP, Brasil.

Tel: 5516 3602-2468, Fax: 5516 3633-6695

e-mail: rmartine@fmrp.usp.br

Recebido para publicação em 21/10/2005

Aceito em 10/8/2006
} 
Cryptococcosis was diagnosed 48 days after delivery. She presented headache and vomiting, which started 40 days after delivery, and persistent fever beginning 15 days before delivery. She was cachectic, pale and conscious and showed nuchal rigidity. Subsidiary tests revealed $8.9 \mathrm{~g} / \mathrm{dL}$ of hemoglobin and white cell number of $6,250 / \mathrm{mm}^{3}$, with $68 \%$ granulocytes. Cerebrospinal fluid (CSF) obtained by spinal puncture revealed 96 cells $/ \mathrm{mm}^{3}$, $24 \mathrm{mg} / \mathrm{dL}$ of protein, and $33 \mathrm{mg} / \mathrm{dL}$ of glucose, with numerous encapsulated fungi identified as Cryptococcus spp by the Indian ink test. Cryptococcus neoformans was isolated from both the blood culture and the CSF.

The patient was treated with amphotericin B at a total dose of $4,075 \mathrm{mg}$, for about 80 days. Cryptococcus was detected in the CSF by the Indian ink test, but the CSF culture became negative after 66 days of treatment. Fluconazole was introduced as maintenance treatment, but the patient returned for evaluation only two months later. She presented intracranial hypertension and died nine days after hospitalization.

The infant was born by vaginal delivery, weighing 2,880g with an Apgar score of 9 and 10 at the $1^{\text {st }}$ and $5^{\text {th }}$ minute, respectively. He was not breast-fed. He evolved with insufficient weight gain and on the $52^{\text {nd }}$ day of life manifested a cough and irregular fever. The infant was anemic, presented an enlarged liver and spleen, diffuse crackles upon auscultation of the lung, as well as candidiasis of the oral mucosa. A chest X-ray revealed an interstitial infiltrate predominating in the bases. The child was treated with amoxicillin and nystatin. At 120 days of life he was hospitalized due to worsening respiratory symptoms and persistent fever. He presented dyspnea, cyanosis, intercostal retractions and tachycardia. A chest X-ray revealed a diffuse bilateral interstitial infiltrate with alveolization in the pulmonary right base. He was treated with ampicillin, gentamicin and sulfamethoxazole-trimethoprim (20mg/kg/day) for 18 days, with no improvement in signs and symptoms. He then manifested respiratory insufficiency and petechial lesions on the arms and trunk, requiring orotracheal intubation, with death occurring 20 days after hospitalization. Cryptococcus neoformans was isolated from a blood culture performed 2 days before death. Histopathological examination of the placenta was not performed. The infant did not receive antifungal treatment because the cryptococcal infection was not diagnosed while he was alive. The anti-HIV test carried out by immunoenzymatic method at 5 days of life was reactive, but PCR for HIV was not accessible in that time.

\section{DISCUSSION}

In the case reported here, vertical transmission of C. neoformans probably occurred, since the disease began in the mother at the end of pregnancy and was later diagnosed as cryptococcosis. Infection of the blood stream permitted the dissemination of the fungus to the meninges and the child was presumably infected inside the uterus. Although it was not possible to examine the placenta, the transmission of $C$. neoformans during the peripartum period was suggested by the early occurrence of respiratory infection in the child, which progressed despite antibacterial treatment, with the yeast isolated later from a blood culture. However, there was no epidemiological data suggesting the acquisition of $C$. neoformans from an environmental source.

In addition to the fact that AIDS favors the occurrence of cryptococcosis, there is evidence that the hormonal and immunological changes inherent to the gestational state favor the onset of diseases caused by intracellular pathogens. Several cases of cryptococcosis affecting pregnant women have been reported, either as pneumonia in previously healthy women or, more commonly, as an infection of the central nervous system ${ }^{18}$. In general, $C$. neoformans is not transmitted to a fetus during pregnancy even when cryptococcal infection is observed in the maternal space of the placenta in a patient ${ }^{5}$. A case of motherchild Cryptococcus transmission with isolation of the yeast from both was reported in 19487. Another probable case of vertical transmission of $C$. neoformans was recently observed in Thailand. The mother, a 26-year-old woman with HIV-1 infection detected during pregnancy, developed pneumonia and cryptococcal meningitis three days after delivery. The child, which was premature and showed insufficient weight gain, but was not infected with HIV, manifested pulmonary and meningeal cryptococcosis at 80 days of age ${ }^{10}$. In this case, whose characteristics were similar to those of the present report, it was also not possible to perform a histological examination of the placenta.

Cryptococcus neoformans infection is infrequent in children, though its incidence has increased due to the greater number of immunodepressed patients and especially due to the increasing survival of children with AIDS $^{4}{ }^{9}$, although cryptococcosis is rarely observed among neonates ${ }^{3}$.

The present report corresponds to a rare case of motherchild transmission of Cryptococcus neoformans by probable hematogenous dissemination during the peripartum period, with an insidious installation of the infection and the occurrence of death in both mother and infant.

\section{REFERENCES}

1. Ely EW, Peacock Jr JE, Haponik EF, Washburn RG. Cryptococcal pneumonia complicating pregnancy. Medicine (Baltimore) 77: 153-167, 1998.

2. Figueiredo JFC, Reis VMF, Machado AA, Oyma SR, Martinez R, Figueiredo LTM, Fonseca BAL, Costa JF, Moya MJ, Castro G. Características clínicas e epidemiológicas de pacientes da região de Ribeirão Preto- SP, Brasil, com aids e infecções oportunistas. Medicina (Ribeirão Preto) 33: 141-146, 2000.

3. Kaur R, Mittal N, Rawat D, Mathur MD. Cryptococcal meningitis in a neonate. Scandinavian Journal of Infectious Diseases 34: 542-143, 2002.

4. Kaur R, Rawat D, Kakkar M, Monga R, Sharma VK. Cryptococcal meningitis in pediatric AIDS. Journal Tropical Pediatrics 49: 124-125, 2003.

5. Kida M, Abramowsky CR, Santoscoy C. Cryptococcosis of the placenta in a woman with acquired immunodeficiency syndrome. Human Pathology 20: 920-921, 1989.

6. Mirza AS, Phelan M, Rimland D, Graviss E, Hamill R, Bandt ME, Garner T, Sattah MLGP, Banghman W, Hajjeh RA. The changing epidemiology of cryptococcosis: an update from population-based active surveillance in 2 large metropolitan areas, 1992-2000. Clinical of Infectious Diseases 36: 789-794, 2003. 
7. Nenhauser EBD, Tucker A. The roentgen changes produced by diffuse torulosis in the newborn. American Journal of Roentgenology 59: 805, 1948.

8. Nucci A, Maciel Jr JA, Queiroz LS, Montenegro MA, De Carvalho RB. Pseudocystic form of neurocryptococcosis in pregnancy. Case report. Arquivos de Neuropsiquiatria 57: 678-682, 1999
9. Pancharoen C, Chindamporn A, Thsyakorn U. Childhood cryptococcosis: an increasing problem in the era of AIDS. Journal of Medical Association of Thailand 84: S86-90, 2001.

10. Sirinavin S, Intusoma U, Tuntirungsee S. Mother-to-child transmission of Cryptococcus neorformans. Pediatric Infectious Disease Journal 23: 278279, 2004. 